\title{
PENGEMBANGAN SPIRITUALITAS REMAJA: MENGAPA REMAJA LAKI-LAKI LEBIH MEMERLUKAN DUKUNGAN KELUARGA DALAM PENGEMBANGAN SPIRITUALITAS
}

\author{
Retno Mangestuti \\ mangestuti@uin-malang.ac.id \\ Rahmat Aziz \\ azira@uin-malang.ac.id \\ Fakultas Psikologi \\ Universitas Islam Negeri Maulana Malik Ibrahim Malang
}

\begin{abstract}
This study aimed to examine the influence on family support for adolescent spirituality. Subjects were 167 students at four universities in Malang. Data were collected by family support scale and daily spiritual experiences scale. The results showed that family support influence on spirituality of $R=.356 p<.50$. Psychological support was a significant factor influencing on adolescent spirituality.
\end{abstract}

Keyword: Family support, material support, psychological support, spirituality

PSIKOISLAMIKA. Jurnal Psikologi Islam (JPI) copyright @ 2017 Pusat Penelitian dan Layanan Psikologi. Volume 14. Nomor 1, Tahun 2017

\section{PENDAHULUAN}

Kajian tentang spiritualitas adalah suatu kajian yang sangat penting karena beberapa penelitian menunjukkan bahwa adanya hasil korelasi yang negatif antara spiritualitas dengan tingkat stres, psikososial, kecemasan dan depresi (Ellison \& Fan, 2008) dan berkorelasi positif dengan penilaian optimisme, dukungan sosial yang dirasakan, dan kepuasan dalam menjalani kehidupan (Kalkstein \& Tower, 2009). Hasil penelitian lain dilakukan oleh Maselko \& Kubzansky (2006) yang menemukan bahwa kegiatan keagamaan dan pengalaman spiritual berkorelasi secara signifikan dengan tingkat kesehatan mental dan kebahagiaan. Artinya semakin sering kegiatan keagamaan dilakukan maka semakin tinggi kemungkinan subjek tersebut untuk menjadi bahagia dalam hidupnya.

Penelitian lain yang sejenis telah dilakukan oleh Holder, Coleman, \& Wallace, (2010) yang menemukan bahwa adanya hubungan yang signifikan antara spiritualitas anak-anak usia 8-12 tahun yang diukur dengan spiritual well-being Questionnaire dengan tingkat kebahagiaan mereka yang diukur dengan oxpord happiness scale short form. Penelitian di Indonesia dengan hasil yanmg sama dilakukan Aziz (2011) yang menemukan bahwa spiritualitas berkorelasi positif dengan tinggginya tingkat kebahagiaan, semakin tinggi tingkat spiritualitas maka semakin tinggi pula tingkat kebahagiaannya.

Data empiris tentang spiritualitas pada remaja telah diteliti oleh Rosalina \& Audrie (2007) yang menemukan bahwa spiritualitas berperan dalam mengatasi masalah yang berhubungan dengan tugastugas perkembangan mereka. Mereka menggunakan ajaran agama yang diperolehnya kemudian diwujudkan dalam kehidupan sehari-hari. Ketika remaja mempunyai spiritualitas yang tinggi maka masalahmasalah yang timbul dapat diatasi baik berhubungan dengan tugas-tugas perkembangan maupun masalah pengambilan keputusan yang berhubungan dengan masa depan mereka. 
Pola perilaku spiritual pada remaja bukanlah sesuatu yang diperoleh secara tiba-tiba melainkan merupakan hasil dari bagaimana remaja tersebut dibesarkan dalam keluarganya, yang didalamnya terjadi proses modeling dan pembelajaran. Menurut Dotson \& Hyatt, (2005) orang tua memegang peranan yang dominan dalam mempengaruhi pola perilaku anak-anak. Oleh karena itu peran orang tua sangatlah penting dalam mengendalikan perilaku remaja, antara lain melalui pola komunikasi dan modelling (pemberian contoh dan teladan).

Penelitian Pearson, Biddle, dan Gorely (2008), menunjukkan bahwa remaja yang mempunyai hubungan yang positif dengan orang tuanya (seperti mempunyai waktu untuk makan bersama dan terlibat dalam aktivitas bersama), ternyata mempunyai pola perilaku yang lebih baik. Selain itu gaya pengasuhan otoritatif yang konsisten antara ayah dan ibu juga dapat memberikan hubungan yang positif dengan kualitas perkembangan remaja (Simon \& Conger, 2007). Hasil penelitian tersebut menunjukkan bahwa meskipun dalam fase perkembangannya remaja mulai membangun hubungan dengan kelompok teman sebayanya, namun interaksi yang positif antara orang tua dengan remaja memberikan kontribusi yang kuat terhadap keberhasilan perkembangan remaja.

Keluarga mempunyai peranan yang sangat penting dalam membantu pengembangan spiritualitas remaja. Penelitian tentang dukungan keluarga dalam hubungannnya dengan perilaku remaja telah dilakukan oleh Rindfleisch, Burroughs, dan Denton (1997) yang menemukan bahwa remaja dari keluarga yang bermasalah mempunyai kecenderungan untuk berperilaku bermasalah dibanding dengan mereka yang berasal dari keluarga utuh. Selanjutnya dijelaskan bahwa dukungan keluarga menjadi mediasi hubungan antara struktur keluarga dengan suatu perilaku. Hasil penelitian diatas menunjukkan bahwa walaupun dalam penelitiannya mereka tidak menyebut secara tegas tentang spiritualitas tapi dapat diduga bahwa sebagai salah satu dari bentuk perilaku, maka spiritualitas dapat dipengaruhi oleh lingkungan keluarga dimana individu tersebut itu berada.

Penjelasan lebih lanjut tentang bentuk dukungan dalam keluarga telah dijelaskan Rindfleisch et al. (1997) yang menyebutkan ada dua bentuk dukungan yang bersifat material dan dukungan yang bersifat psikologis. Selanjutnya dijelaskan bahwa dukungan keluarga yang bersifat psikologis (waktu dan perhatian, disiplin, cinta dan peran bimbingan) memiliki pengaruh yang signifikan terhadap suatu perilaku, sementara dukungan keluarga yang bersifat material (pengeluaran uang, makanan, pakaian) tidak mempunyai pengaruh yang signifikan. Dari uraian diatas dapat disimpulkan bahwa keluarga dalam hal ini adalah orangtua mempunyai peranan yang sangat besar dalam keberhasilan remaja untuk menyelesaikan tugas-tugas perkembangannya baik dalam hal pencarian identitas sampai pada perilaku spiritualitas dalam kehidupan sehari-hari.

Berkenaan dengan spiritualitas pada remaja, mereka akan mengikuti orang tuanya sebagai model yang akan ditiru perilakunya dalam kehidupan sehari-hari, Demikian pula sebaliknya, bila remaja tersebut tidak mendapat dukungan keluarga dalam perilaku sosialnya maka tingkat spiritualpun menjadi rendah Hal ini menunjukkan bahwa perilaku spiritual dapat dijelaskan melalui teori belajar sosial. Dengan demikian dapat dipahami bahwa perilaku spiritualitas remaja yang diukur dengan pengalaman spiritual sehari-hari adalah merupakan akibat dari adanya faktor keluarga yang mendukung pada terjadinya perilaku tersebut.

Spiritualitas merupakan kata yang berasal dari kata spirit yang berarti roh. Kata ini berasal dari kata latin Spiritus yang berarti bernafas. Karena itu spiritual bisa diartikan sebagai roh dan nafas yang berfungsi sebagai energi kehidupan dan membuat seseorang menjadi hidup. Meraviglia (1999) menjelaskan adanya dua dimensi spiritualitas yang mencerminkan nilai-nilai utama. Kedua dimensi tersebut adalah dimensi vertikal dalam hubungan seseorang dengan Tuhan atau tertinggi; dan dimensi horizontal dalam hubungan seseorang dengan alam.

Perkembangan penelitian akhir-akhir ini menunjukan adanya salah satu bidang yang sangat aktif berkembang dalam penelitian empiris yaitu masalah variabel yang berhubungan dengan spiritualitas (McCauley, Tarpley, Haaz, \& Bartlett, 2008). Banyak penelitian menggunakan instrumen psikometrik untuk meneliti tentang variabel spiritual (Miller \& Thoresen, 2003). Para peneliti telah mengukur variabel spiritual baik berupa sikap, pengalaman dan perilaku dengan menggunakan berbagai skala dan kuesioner pada berbagai sampel.

Menurut Ellison \& Fan (2008), skala Pengalaman Spiritual sehari-hari (Daily Spiritual Experience) adalah salah satu alat ukur yang paling inovatif dan sangat signifikan dalam memberikan definisi dan penilaian tentang spiritualitas. Alat ukur ini pada awalnya dikembangkan oleh Underwood dan Teresi 
(2002) yang bentuknya berupa multi-item laporan diri, selanjutnya digunakan untuk mengukur dan mengungkap bagaimana spiritualitas dinyatakan dalam kehidupan sehari.

Pengalaman spiritual sehari-hari didefinisikan sebagai persepsi individu dan emosi yang berkaitan dengan transendensi dalam kehidupan seharihari. Item-itemnya bertujuan untuk mengukur pengalaman rohani pribadi seseorang, bukannya menerima keyakinan atau perilaku tertentu, dengan demikian alat ukur ini tidak secara khusus terikat pada agama tertentu (Underwood \& Teresi, 2002). Selain itu, skala ini bertujuan untuk menilai pengalaman spiritual yang didefinisikan secara lebih luas daripada jenis fenomena tertentu seperti mistis atau ekstrasensor (Underwood, 2006). Penelitian ini bertujuan untuk mengukur spiritualitas yang dioperasionalkan menjadi pengalaman spiritualitas sehari-hari seperti yang diajukan oleh Underwood (2011) yang mendefinisikan pengalaman spiritual sebagai persepsi tentang adanya suatu yang bersifat transenden dalam kehidupan sehari-hari dan persepsi tentang keterlibatan dengan peristiwa atau kejadian transenden dalam kehidupan sehari-hari.

Ada beberapa pengertian yang dapat diajukan dalam memahami pengertian keluarga. Keluarga merupakan unit terkecil dari masyarakat yang terdiri dari kepala keluarga dan beberapa orang yang berkumpul dan tinggal di suatu tempat di bawah satu atap dalam keadaan saling ketergantungan (Departemen Kesehatan Republik Indonesia, 1998). Anggota rumah tangga yang saling berhubungan melalui pertalian darah adaptasi atau perkawinan. Pengertian lain adalah sekelompok manusia yang tinggal dalam suatu rumah tangga dalam kedekatan yang konsisten dan hubungan yang erat.

Hasil penelitian Rindfleisch, Burroughs, dan Denton (1997) menjelaskan adanya dua bentuk dukungan yang bersifat kongkrit dan ada juga yang bersifat abstrak. Selanjutnya dijelaskan bahwa dukungan material (pengeluaran uang, makanan, pakaian) dan dukungan psikologis (waktu dan perhatian, disiplin, cinta dan peran bimbingan). Peran keluarga dalam kehidupan remaja dapat djelaskan dalam perspektif teori Belajar Sosial (Social Learning Theory) yang dikembangkan oleh Albert Bandura (Feist \& Feist, 2011). Ide pokok pemikiran Bandura yang digunakan untuk menjelaskan hasil penelitian ini adalah tentang belajar meniru (imitative learning) yaitu proses belajar dengan cara meniru perbuatan orang lain.
Hubungan antara keluarga dengan spiritual dapat dijelaskan dalam perspektif teori belajar sosial. Konsep utama teori ini menyatakan bahwa proses belajar dapat terjadi dengan mengamati. Karena itu proses belajar remaja akan terjadi dengan cara memperhatikan model dari orangtuanya. Kadang perilaku seseorang bisa timbul hanya karena proses modeling atau peniruan yang merupakan reproduksi perilaku yang langsung dan mekanis (Feist \& Feist, 2009). Karena itu dapat dipahami bahwa spiritualitas remaja mempunyai hubungan yang sangat erat dengan kondisi keluarga dimana remaja tersebut itu berada.

\section{METODE}

Subjek penelitian diambil dari mahasiswa yang kuliah pada tahun pertama di empat perguruan tinggi yang berada di kota Malang yaitu Universitas Islam Negeri (UIN) Malang, Universitas Negeri Malang (UM), Universitas Brawijaya (UB) Malang, dan Universitas Muhammadiyah Malang (UMM). Teknik pengambilan sampel dilakukan secara proporsional. Jumlah subjek penelitian ini sebanyak 167 mahasiswa. Perincian subjek penelitian berdasarkan perbedaan asal perguruan tinggi dan jenis kelamin dapat di lihat pada tabel 1 di bawah ini:

Tabel 1

Subjek penelitian berdasarkan asal perguruan tinggi dan jenis kelamin

\begin{tabular}{lccccccc}
\hline No & Asal & \multicolumn{5}{c}{ Jenis Kelamin } \\
\cline { 3 - 7 } & $\begin{array}{c}\text { Perguruan } \\
\text { Tinggi }\end{array}$ & \multicolumn{2}{c}{ Laki-laki } & \multicolumn{1}{c}{ Perempuan } & \multicolumn{2}{c}{ Jumlah } \\
\cline { 3 - 7 } & F & $\%$ & F & $\%$ & F & $\%$ \\
\hline 1 & UIN & 7 & 4,19 & 34 & 20,36 & 41 & 24,55 \\
\hline 2 & UM & 13 & 7,78 & 17 & 10,18 & 30 & 17,96 \\
\hline 3 & UB & 15 & 8,98 & 32 & 19,16 & 47 & 28,14 \\
\hline 4 & UMM & 18 & 10,78 & 31 & 18,56 & 49 & 29,34 \\
\hline Jumlah & 53 & 31,74 & 114 & 68,26 & 167 & 100 \\
\hline
\end{tabular}

Ada dua jenis model skala yang digunakan pada penelitian ini yaitu skala semantic differential yaitu suatu skala yang bertujuan untuk mengukur sikap, tetapi bentuknya bukan pilihan ganda maupun checklist, tetapi tersusun dalam satu garis kontinum di mana jawaban yang sangat positif terletak dibagian kanan garis, dan jawaban yang sangat negatif terletak dibagian kiri garis, atau sebaliknya. Data yang diperoleh melalui pengukuran dengan skala semantic differential adalah data interval. Skala ini digunakan untuk mengukur variabel dukungan keluarga yang berisi tujuh alternatif jawaban yang disediakan. Skala ini berjumlah 20 item yang mengukur aspek dukungan yang material 
sebanyak 3 item, dan aspek dukungan psikologis sebanyak 7 item. Skala ini mengacu pada konsep yang dikembangkan oleh Rindfleisch, Burroughs, \& Denton (1997) yang membagi jenis dukungan keluarga menjadi dukungan material (uang, makanan, dan pakaian) dan jenis dukungan keluarga psikologis (waktu, perhatian, kedisiplinan, pemberian contoh tauladan, ketrampilan hidup, dukungan emosional dan kasih sayang).

Tabel 2

Distribusi item skala dukungan keluarga

\begin{tabular}{llll}
\hline No & Aspek & Nomor Item & Jumlah \\
\hline $\begin{array}{l}\text { 1. } \\
\text { Dukungan } \\
\text { material }\end{array}$ & 1, 2, 3, & 3 \\
\hline $\begin{array}{l}\text { 2. ukung a n } \\
\text { psikologis }\end{array}$ & $4,5,6,7,8,9,10$ & 7 \\
\hline Jumlah & 10 \\
\hline
\end{tabular}

Skala kedua yang digunakan dalam penelitian ini adalah skala likert yaitu suatu skala yang dapat dipergunakan untuk mengukur sikap, pendapat, dan persepsi seseorang atau sekelompok orang mengenai suatu gejala atau fenomena. Dalam skala Likert terdapat dua bentuk pernyataan yaitu pernyataan positif yang berfungsi untuk mengukur sikap positif, dan pernyataan negatif yang berfungsi untuk mengukur sikap negatif objek sikap. Skor pernyataan positif dimulai dari 1 untuk sangat tidak setuju (STS), 2 untuk tidak setuju (TS), 3 untuk netral (R), 4 untuk setuju (S), dan 5 untuk sangat setuju (SS). Skor pernyataan negative dimulai dari 1 untuk sangat setuju (SS), 2 untuk setuju (S), 3 untuk netral (R), 4 untuk tidak setuju (TS), dan 5 untuk sangat tidak setuju (STS). Skala ini digunakan untuk mengukur variabel pengalaman spiritual yaitu pengalaman seseorang yang menunjukkan adanya aspek spiritual dalam menjalani kehidupan seharihari. Data ini diperoleh melalui alat ukur The Daily Spiritual Experience Scale yang telah dikembangkan oleh Underwood dan Teresi (2002). Skala ini terdiri dari 16 pernyataan favorable yang disusun berbentuk skala Likert dengan lima alternatif jawaban.

Tabel 3

Blue print skala pengalaman spiritual

\begin{tabular}{llll}
\hline No & Indikator & Favorable & Jumlah \\
\hline 1 & Persepsi tentang & $1,3,7,8,9$, & \\
& adanya transendensi & $12,15,16$ & \\
\hline 2 & Persepsi tentang & & \\
& p e r i s t i w a & $2,4,6,10$, & \\
transendensi & $11,13,14$ & \\
\hline Jumlah & 16 \\
\hline
\end{tabular}

Subjek pengujian alat ukur dilakukan pada 148 mahasiswa fakultas psikologi Universitas Islam Negeri (UIN) Malang. Hasil pengujian reliabilitas data skala dukungan keluarga dan pengalaman spiritual sehari-hari ditemukan hasil sebagai berikut:

a. Hasil pengujian reliabilitas skala dukungan keluarga pada aspek dukungan material diperoleh nilai $a=.89$. Dari 3 item yang diuji dinyatakan semunya valid dengan koefisien korelasi item berkisar antara .764 sampai 8.04. Hasil pengujian selengkapnya dapat di lihat dari tabel 4 di bawah ini.

Tabel 4

Hasil pengujian validitas dan reliabilitas skala dukungan keluarga

\begin{tabular}{|c|c|c|c|}
\hline $\begin{array}{c}\text { Aspek } \\
\text { Dukungan } \\
\text { Keluarga }\end{array}$ & $\begin{array}{l}\text { Nomor } \\
\text { Item }\end{array}$ & $\begin{array}{c}\text { Validitas } \\
\text { Item }\end{array}$ & Reliabilitas \\
\hline \multirow{3}{*}{$\begin{array}{l}\text { Dukungan } \\
\text { material }\end{array}$} & 1 & .804 & \multirow{3}{*}{$a=.89$} \\
\hline & 2 & .764 & \\
\hline & 3 & .793 & \\
\hline Dukungan & 4 & .629 & \multirow[t]{7}{*}{$a=.87$} \\
\hline \multirow[t]{6}{*}{ Psikologis } & 5 & .762 & \\
\hline & 6 & .602 & \\
\hline & 7 & .647 & \\
\hline & 8 & .655 & \\
\hline & 9 & .769 & \\
\hline & 10 & .459 & \\
\hline
\end{tabular}

b. Hasil pengujian reliabilitas terhadap skala pengalaman spiritual sehari-hari diperoleh nilai $a=.86$. Dari sejumlah 16 item yang diuji ditemukan adanya 15 item yang valid dan 1 item yang gugur karena koefisien korelasinya kurang dari . 300 . Item yang valid mempunyai koefisien korelasi berkisar antara .319 sampai .627. Hasil pengujian validitas konstruk dengn confirmatory factor analysis diperoleh hasil bobot sumbangan faktor persepsi tentang adanya sesuatu yang bersifat transenden sebesar .81 dan faktor persepsi tentang peristiwa transenden sebesar. 82 . 
Tabel 5

Hasil pengujian validitas dan reliabilitas skala spiritualitas

\begin{tabular}{|c|c|c|c|}
\hline Variabel & $\begin{array}{c}\text { Nomor } \\
\text { Item }\end{array}$ & $\begin{array}{c}\text { Validitas } \\
\text { Item }\end{array}$ & Reliabilitas \\
\hline \multirow[t]{15}{*}{ Spritualitas } & 1 & .592 & $\alpha=.86$ \\
\hline & 3 & .568 & \\
\hline & 7 & .410 & \\
\hline & 8 & .537 & \\
\hline & 9 & .534 & \\
\hline & 12 & .493 & \\
\hline & 16 & .561 & \\
\hline & 2 & .629 & \\
\hline & 4 & .552 & \\
\hline & 5 & .314 & \\
\hline & 6 & .564 & \\
\hline & 10 & .334 & \\
\hline & 11 & .309 & \\
\hline & 13 & .644 & \\
\hline & 14 & .620 & \\
\hline
\end{tabular}

Data dianalisis dengan menggunakan analisis regresi yang bertujuan untuk menguji pengaruh variabel bebas terhadap variabel terikat. Selanjutnya untuk mengetahui peran jenis kelamin sebagai moderator digunakan analisis sub-kelompok yaitu memecah sampel menjadi dua sub-kelompok atas dasar variabel ketiga yang dihipotesiskan sebagai variabel moderator (Ghazali, 2016).

\section{HASIL DAN PEMBAHASAN}

Berdasarkan hasil pengujian dengan analisis deskriptif terhadap variabel dukungan keluarga dan spiritualitas remaja ditemukan bahwa rerata empiris subjek yang diperoleh lebih tinggi dibandingkan dengan rerata hipotetiknya. Hal itu berart bahwa kondisi subjek pada kedua variabel tersebut berada pada kategori tinggi. Subjek penelitian mempunyai lingkungan keluarga kondusif yang dicirikan dengan tingginya dukungan dari keluarga baik yang berdifat material maupun psikologis sehingga skor spiritualisnya menjadi meningkat.

Hasil analisis perbandingan antara mean hipotesis dan mean empiris pada variabel yang diuji menunjukkan bahwa mean empiriknya lebih tinggi dibanding mean hipotesisnya artinya kondisi dukungan keluarga (material dan psikologis) dan spiritual remaja berada pada kategori tinggi. Hasil selengkapnya dapat di lihat pada tabel 6 di bawah ini:
Tabel 6.

Perbandingan skor mean hipotesis dan empiris

\begin{tabular}{llll}
\hline \multirow{2}{*}{ No } & \multirow{2}{*}{ Nama Variabel } & \multicolumn{2}{l}{ Skor Mean } \\
\cline { 3 - 4 } & Hipotetis & Empiris \\
\hline 1 & Dukungan material & 12 & 17.44 \\
\hline 2 & Dukungan psikologis & 28 & 40.05 \\
\hline 3 & Spiritualitas & 45 & 61.88 \\
\hline
\end{tabular}

Hasil analisis regresi ditemukan bahwa dukungan keluarga berpengaruh terhadap spiritualitas remaja sebesar $\mathrm{R}=.356$ dan $\mathrm{R}^{2}=127$. Hal itu berarti bahwa dukungan keluarga berpengaruh terhadap spiritualitas sebesar $12,7 \%$. Selanjutnya dari hasil pengujian parsial kedua aspek dukungan keluarga ditemukan hasil sebagai berikut: faktor dukungan material memberikan sumbangan $B=.156 p>.50$ artinya dukungan material tidak mempunyai pengaruh terhadap tinggi rendahnya spiritualitas remaja. Hal ini berarti bahwa adanya faktor dukungan keluarga yang bersifat material, bukanlah faktor penting dalam fungsinya sebagai variabel yang berpengaruh terhadap spiritualitas, dan faktor dukungan psikologis memberikan sumbangan $B=0,247 p<.50$ artinya dukungan psikologis mempunyai pengaruh terhadap tinggi rendahnya spiritual remaja. Hal ini berarti bahwa dukungan psikologis mempunyai sumbangan yang sangat penting bagi perkembangan perilaku remaja dalam konteks spiritualitasnya.

Dari hasil pengujian diatas dapat disimpulkan bahwa diantara dua aspek dukungan keluarga yang berpengaruh terhadap tinggi rendahnya spiritualitas hanyalah dukungan psikologis yaitu dukungan orangtua dalam bentuk pemberian waktu untuk anak-anak, pemberian perhatian, penciptaan kedisiplinan bagi anak, pemberian contoh tauladan, pemberian bekal berupa pembelajaran bagaimana mempunyai ketrampilan hidup, pemberian dukungan emosional dan pemberian kasih sayang. Hasil penelitian ini sejalan dengan pendapat dan penelitian sebelumnya yang telah dilakukan oleh Robert, Manollis \& Tanner (2001) yang menyatakan bahwa adanya hubungan yang sangat erat antara perilaku beragama (spiritualitas) seseorang dengan kehidupan keluarganya. Kehidupan keluarga yang dimaksud dapat berupa perilaku orangtua yang mampu memberi dukungan psikologis dengan berbagai jenisnya.

Penelitian Rindfleisch et al., (1997) menemukan bahwa anak muda dari keluarga yang bermasalah mempunyai kecenderungan untuk berperilaku bermasalah dibanding dengan mereka yang berasal dari keluarga utuh. Walaupun dalam penelitiannya 
mereka tidak menyebut secara tegas tentang spiritualitas tapi dapat diduga bahwa sebagai salah satu bentuk perilaku, maka spiritualitas yang terkadang diartikan sama dengan perilaku beragama dapat dipengaruhi oleh dukungan keluarga dimana individu tersebut itu berada. Penjelasan lebih lanjut dikatakan bahwa dukungan psikologis memungkinkan keluarga untuk mengimbangi peristiwa negatif lainnya seperti perceraian dan stres, ditambah memberikan kemewahan untuk mendapatkan bantuan tambahan yang diperlukan untuk menyediakan yang dibutuhkan oleh anak-anak. Dukungan material memberikan latihan pada anak-anak agar berperilaku yang baik dan juga memanjakan anak karena perasaan bersalah, sering dikaitkan dengan orangtua yang menghabiskan terlalu sedikit waktu dengan anakanak mereka.

Dalam mendidik anak, orangtua yang bijak akan memberikan lebih dari satu jawaban dan alternatif supaya remaja itu bisa berpikir lebih jauh dan memilih yang terbaik. Orangtua yang tidak mampu memberikan penjelasan dengan bijak dan bersikap kaku akan membuat sang remaja tambah bingung. Remaja tersebut akan mencari jawaban di luar lingkaran orangtua dan nilai yang dianutnya. Ini bisa menjadi berbahaya jika "lingkungan baru" memberi jawaban yang tidak diinginkan atau bertentangan dengan yang diberikan oleh orangtua.

Jika suatu keluarga, dalam kesehariannya terbiasa melakukan kegiatan spiritual atau perilaku beragama maka perilaku tersebut akan dijadikan model oleh anak untuk dilakukan. Ketika remaja masih tinggal dan berada dalam lingkungan keluarga, peranan itu akan terus berlangsung tapi ketika remaja sudah berada jauh dari lingkungan keluarganya, maka perilaku lama yang merupakan hasil dari pemodelan tersebut akan dilakukan terus menerus sampai ditemukan adanya model lain yang bentuknya berbeda.

Selanjutnya hasil pengujian variabel jenis kelamin sebagai moderator pada hubungan antara dukungan keluarga dengan spiritualitas pada kelompok pria ditemukan nilai $\mathrm{R}=.412 \mathrm{R}^{2}=.171$ dan untuk kelompok perempuan ditemukan nilai $\mathrm{R}=.321 \mathrm{R}^{2}$ $=.103$. Hal ini berarti bahwa jenis kelamin berfungsi sebagai variabel moderator yang mempengaruhi

\section{DAFTAR PUSTAKA}

Aisyah, F.F., (2013). Gambaran Spiritualitas Pada Pelaku Konversi Agama, Skripsi. Bandung: Jurusan Psikologi Fakultas IImu Pendidikan Universitas Pendidikan Indonesia kuat atau lemahnya hubungan antara kedua variabel yang diuji.

Hasil di atas menunjukkan nilai $\mathrm{R}^{2}$ kelompok laki-laki lebih tinggi dibanding dengan kelompok perempuan. Hal ini berarti bahwa laki-laki lebih memerlukan dukungan keluarga dalam pengembangan spiritualitasnya jika dibandingkan dengan perempuan. Hasil ini sejalan dengan beberapa penelitian yang telah dilakukan oleh Bryant (2007) yang menemukan bahwa perempuan memang lebih tinggi spiritualitasnya dibandingkan dengan laki-laki. Penelitian Bucho's (2004) yang menemukan bahwa spiritual dan keberagamaan lebih tinggi pada subjek perempuan daripada laki-laki. Penelitian lainnya Hammermeister, et al (2005) menemukan yang sama bahwa perempuan lebih tinggi dibanding laki-laki dalam hal spiritualitas. Beberapa penelitian diatas menunjukkan bahwa perempuan lebih tinggi tingkat spiritualitasnya dibanding dengan laki-laki. Hal ini menurut (Rich, 2012) diduga karena spiritualitas itu sifatnya melibatkan aspek personal, yang pada aspek ini ternyata perempuan memang lebih tinggi dibanding laki-laki.

Tingginya perempuan dalam hal spiritualitas dibandingkan laki-laki menunjukkan bahwa memang jenis kelamin dapat berperan sebagai variabel moderator yang berfungsi memperkuat atau memperlemah pada hubungan antara dukungan orangtua dan spiritualitas pada remaja. Hasil ini berimplikasi praktis pada pola pengasuhan orangtua dalam memperlakukan para remaja. Orangtua harus lebih memberikan dukungan, khususnya dukungan psikologis yang lebih tinggi terhadap remaja lakilaki dibanding remaja perempuan.

Penjelasan hasil penelitian ini dalam perspektif teori belajar sosial Bandura, 1977) dapat dijelaskan sebagai berikut: perkembangan spiritual seorang anak banyak dipengaruhi oleh lingkungannya maka anak memperoleh nilai-nilai spiritual dari lingkungannya, terutama dari orangtuanya. Dia belajar untuk mengenal nlai-nilai dan berperilaku sesuai dengan nilai-nilai tersebut. Bagi anak, orangtua dapat dijadikan "role model" dalam melakukan perilaku tertentu. Walaupun, anak tersebut akan menyeleksi mana perilaku yang pantas untuk dicontoh dan mana perilaku yang tidak pantas untuk dicontoh.

Aziz, R. (2011). Pengalaman Spiritual dan Kebahagiaan Pada Guru Agama Sekolah Dasar. Proyeksi, 6(2), 1-11 
Bandura, A. (1977). Social Learning Theory. Englewood Cliffs, Englewood Cliffs, New Jersey: Prentice Hall Inc.

Bryant, A. N. (2007). Gender Differences in Spiritual Development During the College Years. Sex Roles, 56(11-12), 835-846. https://doi.org /10.1007/s11199-007-9240-2

Dotson, M. J., \& Hyatt, E. M. (2005). Major influence factors in children's consumer socialization. Journal of Consumer Marketing, 22(1), $35-42$.

Dunn, K.S.; Wordlaw, S.L.; Chapleski, (2003), E. Everyday spirituality in central city elders. Journal of Religioun and Spritual Aging, 15, 41-59.

Ellison, C.G.; Fan, D. Daily spiritual experiences and psychological well-being among US adults. Soc. Indic. Res. 2008, 88, 247-271.

Feist, J., \& Feist, G.J., (2009). Theories of Personality, Avenue of Americas, New Jersey: Mc Graw Hil

Ghazali, I., (2016), Aplikasi Analisis Multivariat dengan Program IBM SPSS 23, Semarang: Badan Penerbit Universitas Dipenogoro

Hammermeister, Flint, El-Alayli, Ridnour, \& Peterson (2005), Gender differences in spiritual wellbeing: are females more spiritually-well than males? American Journal of Health Studies, 20(2), 80-84

Holder, M. D., Coleman, B., \& Wallace, J. M. (2010). Spirituality, Religiousness, and Happiness in Children Aged 8-12 Years. Journal of Happiness Studies, 11(2), 131-150

Kalkstein, S.. \& Tower, R.B. (2009). The Daily Spiritua IExperience Scale and well-being: Demographic comparisons and scale validation with older Jewish adults and a diverse internet sample. Journal of Religion Health. 48, 401-417.

Maselko, J. \& Kubzansky, L.D. (2006). Gender differences in religious practices, spiritual experiences and health: Results from the US General Social Survey, 62(11), 2848-2860
McCauley, J.; Tarpley, M.J.; Haaz, S.; Bartlett, S.J. (2008). Daily spiritual experiences of older adults with and without arthritis and the relationship to health outcomes. Arthritis Rheum. 59, 122-128.

Meraviglia, M.G. (1999). Critical analysis of spirituality and its empirical indicators. Journal of Holistic Nursing, 17(1), 18-33.

Miller, W. R. , \& Thoresen, C. E. (2003). Spirituality, religion, and health: An emerging research field. [Special issue]. American Psychologist, 58, 24-35

Miller, W.R.; Forcehimes, A.; O’Leary, M.J.; LaNoue, M.D. (2008) Spiritual direction in addiction treatment: Two clinical trials. Journal of Subst. Abus. Treat. 35, 434-442.

Pearson, N., Biddle, S.J.H., \& Gorely, T. (2008). Family correlates of breackfast consumption among children and adolescenta: a systematic review. Appetite, 52, 1-7.

Rich, I. I. (2012). Gender and Spirituality: Are Women Really More Spiritual? Thesis, Liberty University

Rindfleisch, A., Burroughs, J. E., \& Denton, F. (1997). Family Structure, Materialism, and Compulsive Consumption. Journal of Consumer Research, 23(4), 312-325. https: // doi.org/10.2307/2489568

Rogers, M.B., Loewenthal, K.M., Lewis, C.A., Amlôt, R., Cinnirella, M., \& Ansari, H. (2007). The role of religious fundamentalism in terrorist violence: A social psychological analysis. International Review of Psychiatry, 19(3), 253-262.

Rosalina, K.J., \& Audrie, A., (2007), Gambaran Peran Religiusitas Pada Remaja Akhir Ketika Menghadapi Masalah, Tesis, Jakarta: Fakultas Psikologi Atmajaya

Simon, G.L., \& Conger, R.D. (2007). Linking fathermother differences in parenting to a typology of parenting style and adolescent outcomes. Journal of Family Issues, 28 (2), 212-241. 